\title{
Oral tissues regeneration using intraoral mesenchymal stem cells
}

\author{
Pascale Fagalde ${ }^{1}$, David Reininger ${ }^{2}$
}

${ }^{1}$ DDS, private practice

${ }^{2}$ DDS, PhD, Master in Oral Surgery and Implantology, Assistant professor, Universidad Mayor, Chile

Correspondence:

Universidad mayor

Science Faculty, Dentistry School

Avda Liber Bernardo O'Higgins 2013

Santiago, Región Metropolitana, Chile

david.reininger@umayor.cl

Fagalde P, Reininge D. Oral tissues regeneration using intraoral mesenchymal stem cells. J Clin Exp Dent. 2021;13(3):e268-77.

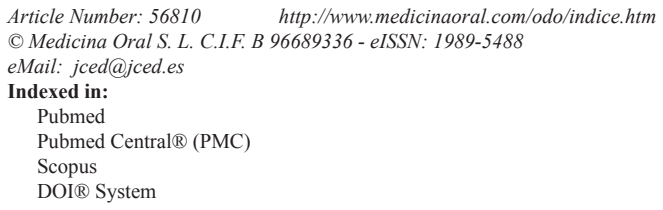

\begin{abstract}
Background: Oral pathologies or some treatments can cause facial and functional alterations, being fundament to retrieve those functions restoring the original anatomy of the lost tissues. On this purpose, various techniques have been studied, one of these was the tissue engineering. Mesenchymal stem cells (MSC) are multipotent adult stem cells. The MSC in the oral cavity have been striking for regenerative therapies by its high plasticity, good interaction with scaffolds and growth factors, good proliferation and differentiation, they are also easy to obtain. Objective: The objective of this study was to describe the current uses of the intraoral MSC for the regeneration of the tissues of the oral cavity.

Material and Methods: An electronic research was made in the databases PubMed, Cochrane Library, Google Scholar, Scopus and EBSCO between 2000 to 2018.

Results: 21 articles were included. 13 were studies in vivo and 8 were studies in humans. The site mostly used as a giver site was the dental pulp. Intraoral MSC are able to regenerate the pulp dentin complex, alveolar bone and periodontium.

Conclusions: Intraoral MSC come from easy access areas, less traumatic interventions and have high potential to regenerate intraoral tissues in comparison to MSC from other sites of the body which allows a more predictable oral tissues regeneration.
\end{abstract}

Key words: Oral stem cells, oral cavity, regeneration, tissue engineering.

\section{Introduction}

Mesenchymal stem cells are multipotent adult stem cells. They were discovered by Friedenstein and his collaborators in the $70 \mathrm{~s}$, who conducted studies to determine the biological characteristics of mesenchymal stem cells derived from the bone marrow (1). One of its main functions is to maintain and repair cells in the tissue in which they are found, as well as maintain the cell population. Among its most important characteristics is that they have the ability to differentiate into adipocytes, chondrocytes and osteoblasts in in vitro conditions. In addition, mesenchymal stem cells have the ability to evade the immune system by being immunomodulatory, which allows them to be used with therapeutic roles $(1,2)$. 
The first site intervened to obtain mesenchymal stem cells was the bone marrow of adult patients. Although its characteristics were optimal, it was observed that the number of progenitor cells in adult tissue was quite low compared to the total number of cells extracted, in a ratio of $1 /$ 104-106. This is why it was necessary to carry out in vitro expansions to increase their number. In addition, the number of cells decreased as a function of increasing the patient's age (3). On the other hand, obtaining mesenchymal stem cells from the bone marrow proved to be a very invasive, painful procedure with infectious complications (1).This is why they started looking for new sites that had mesenchymal stem cells which would allow a minimum of discomfort for the patient and that were present in greater quantities $(1,4)$.

From this, it is that the oral cavity became one of the most accessible sites for obtaining mesenchymal stem cells (1), in which different sites have been identified that possess them such as the bone marrow of the alveolar bone (BMSCs), the oral mucosa (OMSCs), the periosteum (PSCs), the salivary glands (SGSCs), the adipose tissue (ASC), the dental pulp (DPSCs), the dental pulp of exfoliated teeth (SHEDs), the periodontal ligament (PLSCs), the dental follicle (DFSCs), the dental germ (GDSCs), the apical papilla (SCAP) and the inflamed periapical tissues (iPAPs) (5).

Existing reviews describe mostly in vitro studies, with bone regeneration being the most performed action. Therefore, the aim of this review is to extend the search of the different regenerative uses that intra-oral mesenchymal stem cells present not only at the level of bone regeneration, but also to describe their uses in other types of tissues of the oral cavity, including exclusively studies in vivo or in humans.

\section{Material and Methods}

A review of the literature was carried out between 2000 and 2018 in the databases PubMed, Cochrane Library, EBSCO, Scopus and Google Scholar, performing the search strategy detailed in Table 1.

All studies carried out in vivo and in humans, prospective and retrospective cohort, clinical trials, case/control studies, including articles in English, Spanish and French, where intraoral mesenchymal stem cells were used (regardless of the autologous intraoral donor site) to regenerate intraoral defects were included. We excluded all those in vitro studies, studies that did not specify the mesenchymal stem cell used, studies that included patients or animals with some underlying disease or that were under pharmacological therapy that affected the regeneration of tissues, immunocompromised or immunosuppressed, patients that had been irradiated in the craniofacial region in the last 6 months or were in treatment with intravenous bisphosphonates and in the case of orally bisphosphonates should not be more than 3 years.

\section{Results}

From the electronic search, a total of 1428 publications were found, selecting a total of 21 articles according to the inclusion and exclusion criteria (Fig. 1, Table 2, 2 cont., 2 cont.-1, 2 cont.-2). Of the 21 articles included,

Table 1: Search strategy according to database.

\begin{tabular}{|c|c|}
\hline DATA BASES & SEARCH STRATEGY \\
\hline Pul & $\begin{array}{l}\text { (((((()“Stem Cells”[Mesh]) OR “Stem Cell transplantation”[Mesh]) AND “Tooth Components”[Mesh]) } \\
\text { OR “Periodontium”[Mesh]) OR “Salivary glands”[Mesh]) OR “Periosteum”[Mesh]) AND “Stomato- } \\
\text { gnathic System”[Mesh]) AND “Regenerative Medicine”[Mesh]) OR (periodontal ligament OR dental } \\
\text { pulp OR apical papilla OR dental follicle OR gingival tissue OR alveolar bone OR periodontium OR } \\
\text { tooth germ OR exfoliated deciduous teeth OR periosteum OR salivary glands OR oral fat pad OR peri- } \\
\text { apical inflamed tissue) AND regenerative medicine AND mouth }\end{array}$ \\
\hline Cochrane Library & "Mesenchymal Stem Cells" AND “Oral Regenerative Medicine" \\
\hline EBSCO & 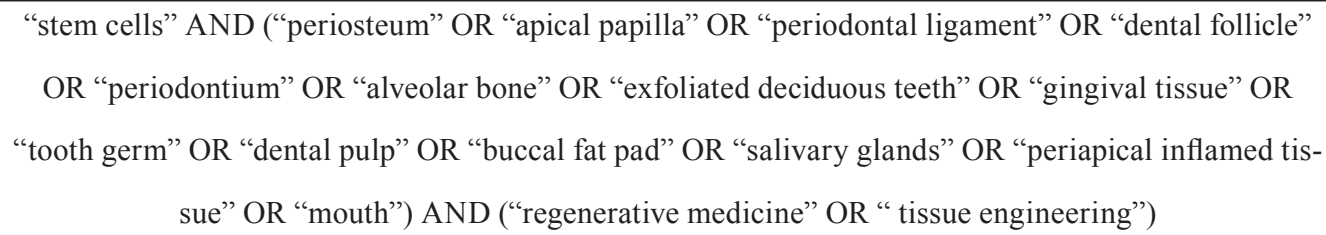 \\
\hline Scopus & ("stem cells" AND "mouth" AND "tissue engineering ") \\
\hline Google Scholar & generative medicine" or "tissue engineering") \\
\hline
\end{tabular}




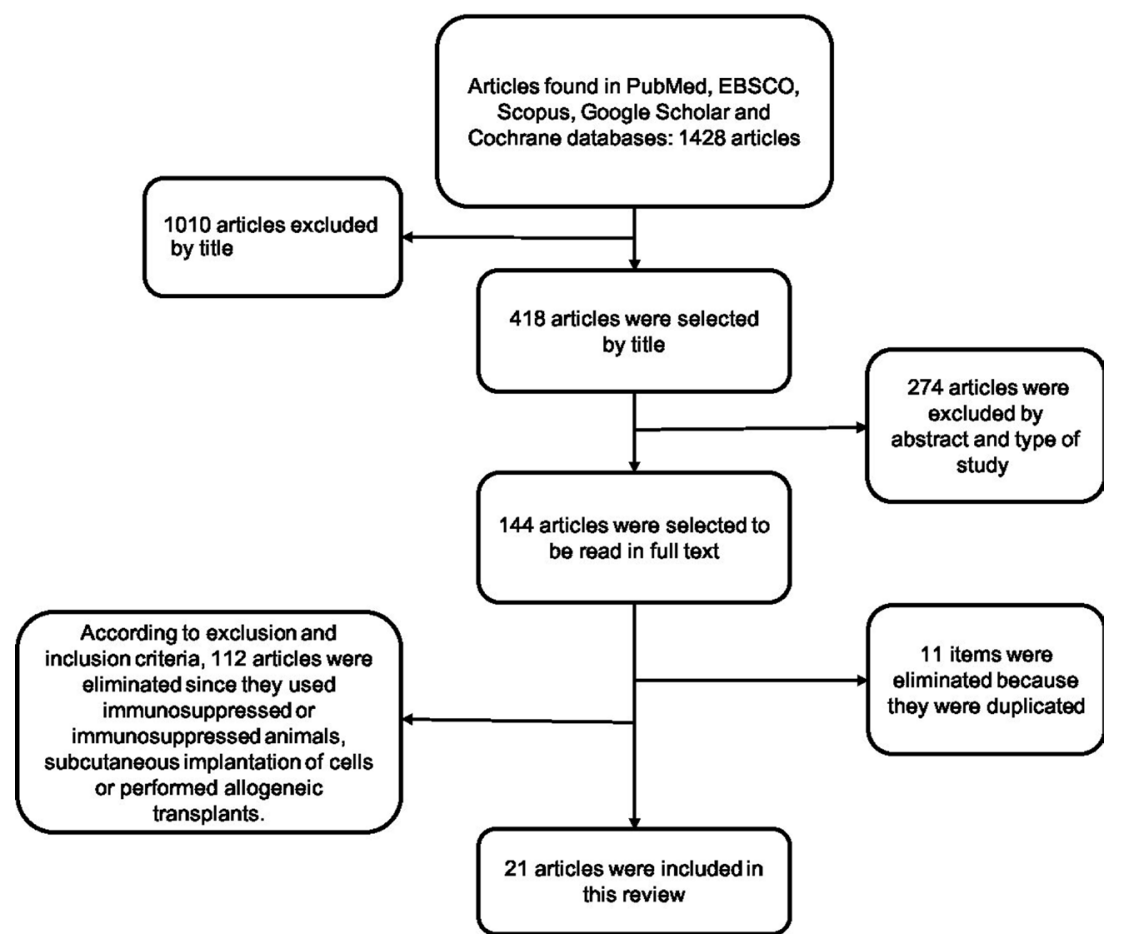

Fig. 1: Summary of search results.

Table 2: Summary of the included studies.

\begin{tabular}{|c|c|c|c|c|c|c|}
\hline Author & $\begin{array}{l}\text { Type of } \\
\text { MSC }\end{array}$ & Scaffold & Regeneration & Total Sample & $\begin{array}{c}\text { Transplanted Site and } \\
\text { Method }\end{array}$ & Conclusion \\
\hline $\begin{array}{l}\text { Redondo et } \\
\text { al. (2018) }\end{array}$ & $\begin{array}{l}\text { BMSCs of } \\
\text { maxillary } \\
\text { bone }\end{array}$ & $\begin{array}{l}\text { Serum cross } \\
\text { liked } \\
\text { scaffols } \\
\text { (biomax) }\end{array}$ & Alveolar bone & $\begin{array}{l}9 \text { patients with } \\
\text { radicular cysts } \\
\text { between } 21 \text { to } \\
50 \text { years }\end{array}$ & $\begin{array}{l}\text { - BMSCs of the maxillary } \\
\text { bone. } \\
\text { - Scaffolding plus cells } \\
\text { injected into cavity of max- } \\
\text { illary radicular cysts. }\end{array}$ & $\begin{array}{l}\text { Bone regeneration was observed } \\
\text { in all cases when implanting } \\
\text { the cells in the space where the } \\
\text { cyst was. }\end{array}$ \\
\hline $\begin{array}{l}\text { Barbier et al. } \\
\text { (2018) }\end{array}$ & DPSCs & $\begin{array}{l}\text { Collagen } \\
\text { Matrix }\end{array}$ & Alveolar bone & $\begin{array}{l}32 \text { patients } \\
\text { between } 18 \text { to } \\
30 \text { years old. }\end{array}$ & $\begin{array}{l}\text { - DPSCs of impacted impac- } \\
\text { ted mandibular third molars } \\
\text { - Duration of } 6 \text { months } \\
\text { comparing the immediate } \\
\text { post exodontia control }\end{array}$ & $\begin{array}{l}\text { There was no significant } \\
\text { difference between the } \\
\text { operated group and the control } \\
\text { with regard to the absorption of } \\
\text { the alveolus after an impacted } \\
\text { third molar extraction. No bone } \\
\text { regeneration was obtained with } \\
\text { DPSCs. }\end{array}$ \\
\hline $\begin{array}{l}\text { Mangione et } \\
\text { al.(2017) }\end{array}$ & DPSCs & Hidrogel & Dental pulp & $\begin{array}{l}3 \text { healthy mini- } \\
\text { pigs from } 18 \text { to } \\
20 \text { months }\end{array}$ & $\begin{array}{c}\text { - DPSCs of lateral } \\
\text { incisors were implanted } \\
\text { after performing cameral } \\
\text { pulpotomy of premolars and } \\
\text { molars in the Split mouth } \\
\text { model. }\end{array}$ & $\begin{array}{l}\text { There was no pulpal } \\
\text { regeneration with this protocol. It } \\
\text { is rather an osteodentin, } \\
\text { different from the native dentine. }\end{array}$ \\
\hline $\begin{array}{l}\text { Nakashima et } \\
\text { al. (2017) }\end{array}$ & DPSCs & $\begin{array}{l}\text { G-CSF + ate- } \\
\text { locollagen }\end{array}$ & $\begin{array}{l}\text { Dental pulp } \\
\text { and dentine }\end{array}$ & $\begin{array}{l}5 \text { pacientes con } \\
\text { pulpitis irrever- } \\
\text { sible }\end{array}$ & $\begin{array}{l}\text {-DPSCs of teeth with } \\
\text { irreversible pulpitis } \\
\text { transplanted to the } \\
\text { pulpectomized teeth. }\end{array}$ & $\begin{array}{l}\text { Pulpal regeneration was } \\
\text { observed with sensitivity }+ \text { and } \\
\text { dentinal regeneration. }\end{array}$ \\
\hline $\begin{array}{l}\text { Chen et al. } \\
\text { (2016) }\end{array}$ & PLSCs & $\begin{array}{l}\text { GTR }+ \text { Bio- } \\
\text { oss } \AA\end{array}$ & Alveolar bone & $\begin{array}{l}30 \text { patients } \\
\text { between } 18 \text { to } \\
65 \text { years old }\end{array}$ & $\begin{array}{l}\text { - DPSCs of third molars. } \\
\text { - Control group } 21 \text { teeth: } \\
\text { bio-oss }{ }^{\circledR}+\text { GTR } \\
\text { - Group operated } 20 \text { teeth: } \\
\text { bio-oss }{ }^{\circledR}+\text { GTR + DPSCs }\end{array}$ & $\begin{array}{l}\text { Both groups showed bone rege- } \\
\text { neration, the difference was not } \\
\text { statistically significant. }\end{array}$ \\
\hline
\end{tabular}


Table 2 cont.: Summary of the included studies.

\begin{tabular}{|c|c|c|c|c|c|c|}
\hline $\begin{array}{l}\text { Monti et al. } \\
\text { (2016) }\end{array}$ & DPSCs & $\begin{array}{l}\text { Collagen } \\
\text { Sponge }\end{array}$ & Alveolar bone & $\begin{array}{l}6 \text { patients }(4 \\
\text { women and } 2 \\
\text { men) between } \\
22 \text { to } 60 \text { years }\end{array}$ & $\begin{array}{l}\text { - DPSCs of extracted teeth } \\
\text { - Alveolus with the sponge } \\
\text { soaked in MSC obtained } \\
\text { from the pulp. }\end{array}$ & $\begin{array}{l}\text { DPSCs are capable of regenera- } \\
\text { ting alveolar bone suitable for } \\
\text { implants. }\end{array}$ \\
\hline $\begin{array}{l}\text { Iohara et al. } \\
\text { (2016) }\end{array}$ & DPSCs & $\begin{array}{l}\text { Atelocolla- } \\
\text { gen }\end{array}$ & Dental pulp & $\begin{array}{l}5 \text { dogs between } \\
8 \text { to } 10 \text { months } \\
\text { of age }\end{array}$ & $\begin{array}{l}\text { - DPSCs of the upper cani- } \\
\text { nes extracted. } \\
\text { - Pulpectomy to the upper } \\
\text { lateral incisors, and lower } \\
\text { incisors with apical closure } \\
\text { and enlargement of the } \\
\text { apical foramen of } 1 \mathrm{~mm} \text {. }\end{array}$ & $\begin{array}{l}\text { Complete regeneration of dental } \\
\text { pulp regeneration of less minera- } \\
\text { lized dentine. }\end{array}$ \\
\hline $\begin{array}{l}\text { Khojasteh et } \\
\text { al. (2016) }\end{array}$ & ASCs & $\begin{array}{c}\text { Block of } \\
\text { iliac crest, } \\
\text { with FDBA } \\
\text { and collagen } \\
\text { membrane }\end{array}$ & Alveolar bone & $\begin{array}{l}8 \text { patients with } \\
\text { mandibular } \\
\text { atrophy, be- } \\
\text { tween } 25 \text { and } \\
60 \text { years }\end{array}$ & $\begin{array}{l}\text { - ASCs of the adipose body } \\
\text { of the cheek, } \\
\text { - Molar to molar incision } 10 \\
\text { mm away from maxillary } \\
\text { alveolar ridge } \\
\text { - Cells with collagen mem- } \\
\text { brane, FDBA and bone of } \\
\text { the autogenous iliac crest } \\
\text { in the operated group (4) } \\
\text { and control group without } \\
\text { SC.. (4) }\end{array}$ & $\begin{array}{l}\text { Both groups showed bone regen- } \\
\text { eration, the difference was not } \\
\text { statistically significant. DPSCs } \\
\text { are capable of regenerating al- } \\
\text { veolar bone suitable for implants. } \\
\text { Complete regeneration of dental } \\
\text { pulp regeneration of less miner- } \\
\text { alized dentin. Bone regeneration } \\
\text { when using together mesenchy- } \\
\text { mal cells of the adipose body of } \\
\text { the cheek in conjunction with the } \\
\text { iliac crest graft. }\end{array}$ \\
\hline $\begin{array}{l}\text { Nakajima et } \\
\text { al. (2014) }\end{array}$ & TGSCs & $\begin{array}{l}\text { Beta-TCP+ } \\
\text { poligricolic } \\
\quad \text { acid }\end{array}$ & Periodontium & $\begin{array}{c}6 \text { female one } \\
\text { year old beagle } \\
\text { dogs }\end{array}$ & $\begin{array}{l}\text { - Granulation tissue of } \\
\text { alveoli post exodonces ( } 3 \\
\text { days). } \\
\text { - Periodontal defect is re- } \\
\text { generated mesially of the } \\
\text { first mandibular molar of } \\
\text { each dog. } \\
\text {-Fill the defect with SC } \\
\text { previously obtained from } \\
\text { the granulation tissue. }\end{array}$ & $\begin{array}{l}\text { Cells of alveolar granulation } \\
\text { tissue promote periodontal re- } \\
\text { generation (LP, cement and bone) }\end{array}$ \\
\hline $\begin{array}{l}\text { Mouraret et } \\
\text { al. (2014) }\end{array}$ & PSCs & $\begin{array}{l}\text { Collagen } \\
\text { Sponge }\end{array}$ & Alveolar bone & $\begin{array}{l}17 \text { Mice, be- } \\
\text { tween } 3 \text { to } 5 \\
\text { months. }\end{array}$ & $\begin{array}{l}\text { - Incisions behind the upper } \\
\text { incisor perpendicular to the } \\
\text { bone crest } \\
\text { - Periosteum within these } \\
\text { incisions alone or with colla- } \\
\text { gen sponge. } \\
\text { - Same procedure in the } \\
\text { tibia of each mouse. }\end{array}$ & $\begin{array}{l}\text { Little regeneration with tun- } \\
\text { neling technique, good regenera- } \\
\text { tion when using collagen sponge. }\end{array}$ \\
\hline $\begin{array}{l}\text { Murakami et } \\
\text { al. (2014) }\end{array}$ & DPSCs & $\begin{array}{l}\text { Atelocollaen } \\
+ \text { (G-CSF) }\end{array}$ & Dental pulp & $\begin{array}{l}6 \text { Beagle } \\
\text { female dogs, } \\
\text { between } 9 \text { to } 11 \\
\text { months of age. }\end{array}$ & $\begin{array}{c}\text { - DPSCs of incisors, } \\
\text { - Enlargement } 0.6 \mathrm{~mm} \text { the } \\
\text { apical foramen. } \\
\text { - Sample of adipose tissue of } \\
\text { the abdominal subcutaneous } \\
\text { and bone marrow of the } \\
\text { sternum. } \\
\text { - SC transplant inside the } \\
\text { incisor duct. }\end{array}$ & $\begin{array}{l}\text { Greater regeneration of the pulp } \\
\text { matrix when using the SC from } \\
\text { the bone marrow and fat cells } \\
\text { compared to those of the dental } \\
\text { pulp, but with the DPSCs, more } \\
\text { vascularization and innervation } \\
\text { was seen. }\end{array}$ \\
\hline
\end{tabular}


Table 2 cont.-1: Summary of the included studies.

\begin{tabular}{|c|c|c|c|c|c|c|}
\hline $\begin{array}{l}\text { Shiehzadeh } \\
\text { et al. (2014) }\end{array}$ & $\begin{array}{c}\text { SCAPs, } \\
\text { SHEDSCs } \\
\text {, Periapical } \\
\text { SC. }\end{array}$ & $\begin{array}{c}\text { Poli } \\
\text { (lactide-co } \\
\text { glycolide)- } \\
\text { polyethyl- } \\
\text { eneglycol } \\
\text { (PLGA-PEG) }\end{array}$ & Alveolar bone & $\begin{array}{l}3 \text { patients with } \\
\text { apical perio- } \\
\text { dontitis, of } \\
20,15 \text { and } 30 \\
\text { years. }\end{array}$ & $\begin{array}{l}\text {-Case 1: Cells extracted } \\
\text { from the immature apex. } \\
\text {-Case 2: Cells of the pulp of } \\
\text { exfoliated teeth. } \\
\text {-Case 3: Cells of the apical } \\
\text { papilla of a third molar } \\
\text { - In all three cases, the SRC } \\
\text { of the teeth was filled with } \\
\text { the SCs next to the injec- } \\
\text { tion-shaped scaffolding. } \\
\text {-Regular clinical and radio- } \\
\text { graphic controls and obtura- } \\
\text { tion with gutta-percha. }\end{array}$ & $\begin{array}{l}\text {-Case 1: Apical closure, decrea- } \\
\text { se in the radio apical and asymp- } \\
\text { tomatic lucidity. } \\
\text {-Case 2: Satisfactory recovery of } \\
\text { the periapical lesion. } \\
\text {-Case 3: Repaired bone defect } \\
\text { and asymptomatic tooth }\end{array}$ \\
\hline $\begin{array}{l}\text { Iohara et al. } \\
\text { (2013) }\end{array}$ & DPSCs & $\begin{array}{l}\text { Atelogollaen } \\
+(\text { G-CSF })\end{array}$ & Dental pulp & $\begin{array}{l}18 \text { Beagle dogs, } \\
\text { between } 9 \text { to } 11 \\
\text { months }\end{array}$ & $\begin{array}{l}\text { - Extraction DPSCs } \\
\text { - Enlargement of the apex in } \\
\text { incisors. } \\
\text { - Duct filling with DPSCs } \\
\text { with scaffolding. }\end{array}$ & $\begin{array}{l}\text { Regeneration complete pulp with } \\
\text { vasculogenesis, nerurogenesis } \\
\text { and dentineogenesis. }\end{array}$ \\
\hline $\begin{array}{l}\text { Kodonas et } \\
\text { al. (2012) }\end{array}$ & DPSCs & $\begin{array}{l}\text { Atelogco- } \\
\text { llageno + } \\
\text { PLGA }\end{array}$ & $\begin{array}{l}\text { Dental pulp } \\
\text { and dentine }\end{array}$ & $\begin{array}{l}3 \text { mini pigs } 7 \\
\text { months old. }\end{array}$ & $\begin{array}{l}\text { - Extraction DPSCs im- } \\
\text { mature permanent incisors } \\
\text { and premolars without } \\
\text { erupting. } \\
\text { - } 1 \text { year after the rest of } \\
\text { the incisors and premolars } \\
\text { were removed and } 32 \text { root } \\
\text { implants were created with } \\
\text { the teeth. } \\
\text { - Filling with the collagen } \\
\text { scaffold with DPSCs and } \\
\text { implanted in the alveoli } \\
\text { after extraction of the jaw. - } \\
5 \text { alveoli without cells with } \\
\text { scaffolds were the negative } \\
\text { controls. }\end{array}$ & $\begin{array}{l}\text { Formation of a new dentin ma- } \\
\text { trix within the canal. Both sca- } \\
\text { ffolds worked the same. }\end{array}$ \\
\hline $\begin{array}{l}\text { Lovelace et } \\
\text { al. (2011) }\end{array}$ & SCAPs & None & $\begin{array}{l}\text { Dental pulp } \\
\text { and dentine }\end{array}$ & $\begin{array}{l}.8 \text { patients, } 5 \\
\text { men and } 3 \text { wo- } \\
\text { men between } 2 \\
\text { to } 9 \text { years old. }\end{array}$ & $\begin{array}{l}\text { - Revascularization treat- } \\
\text { ment. } \\
\text { - Third session the blood } \\
\text { samples were taken in order } \\
\text { to compare the mesenchy- } \\
\text { mal cells and their maraca- } \\
\text { dores in the apical blood and } \\
\text { systemic blood. }\end{array}$ & $\begin{array}{l}\text { Apical regeneration using the } \\
\text { revascularization technique. } \\
\text { The apical bleeding contributes } \\
\text { the mesenchymal cells that reach } \\
\text { the canal and allow the apical } \\
\text { closure. }\end{array}$ \\
\hline $\begin{array}{l}\text { Iohara et al. } \\
\text { (2011) }\end{array}$ & DPSCs & $\begin{array}{l}\text { Nitta gelatin } \\
\text { (mix colla- } \\
\text { gen I and III) } \\
\quad+\text { SDF-1 }\end{array}$ & $\begin{array}{l}\text { Dental pulp } \\
\text { and dentine }\end{array}$ & 15 adult dogs & $\begin{array}{l}\text {-DPSC extraction of teeth } \\
\text { with apical closure. } \\
\text {-Agmentation of the apical } \\
\text { foramen } 0.7 \mathrm{~mm} \\
\text {-Fill the ducts with the cells } \\
\text { and the scaffolding. } \\
\text {-Groups: transplantation } \\
\text { of pulp mesenchymal cells } \\
\text { + SDF-1 (10), pulp cell } \\
\text { transplant + SDF-1 (5), } \\
\text { transplantation of adipose } \\
\text { mesenchymal cells + SDF-1 } \\
\text { (5), transplantation of SDF-1 } \\
\text { alone (5), transplantation of } \\
\text { only pulpal mesenchymal } \\
\text { cells without SDF-1 (5), tee- } \\
\text { th only with scaffolding (5). } \\
\text {-Control } 5 \text { healthy teeth. }\end{array}$ & $\begin{array}{l}\text { The use of CD105 + MSC of the } \\
\text { dental pulp with SDF- } 1 \text { allows } \\
\text { the complete regeneration of } \\
\text { the dental pulp with vessels, } \\
\text { nerves and dentine in addition to } \\
\text { the apical closure. The fat cells } \\
\text { showed low regenerative poten- } \\
\text { tial, dental pulp cells also rege- } \\
\text { nerated, but in lesser quantity. }\end{array}$ \\
\hline
\end{tabular}


Table 2 cont.-2: Summary of the included studies.

\begin{tabular}{|c|c|c|c|c|c|c|}
\hline $\begin{array}{l}\text { Yamada et al. } \\
\text { (2011) }\end{array}$ & DPSCs & PRP & Alveolar bone & $\begin{array}{c}\text { Adult mongrel } \\
\text { dogs } \\
.\end{array}$ & $\begin{array}{l}\text {-Extraction of the first mo- } \\
\text { lar and premolars extraction } \\
\text { of DPSCs. } \\
\text {-Bone defect employment } \\
\text { - Sample of the bone ma- } \\
\text { rrow of the iliac crest. } \\
\text {-Prepletion of defects in a } \\
\text { random manner with PRP, } \\
\text { PRP + pulpal mesenchymal } \\
\text { cells and PRP + SC of the } \\
\text { bone marrow. }\end{array}$ & $\begin{array}{l}\text { Good bone regeneration with } \\
\text { the cells of the dental pulpy of } \\
\text { the bone marrow. There was no } \\
\text { rejection in the SHEDsde puppy } \\
\text { experiment. }\end{array}$ \\
\hline $\begin{array}{l}\text { Ito } \text { et al. } \\
\text { (2011) }\end{array}$ & DPSCs & PRP & Alveolar bone & $\begin{array}{c}3 \text { dogs } 2 \text { years } \\
\text { old }\end{array}$ & $\begin{array}{l}\text { - Extraction of first molars } \\
\text { and premolars } \\
\text { - } 3 \text { bone defects in which } \\
\text { PRP was placed in only one, } \\
\text { in another PRP + DPSCs } \\
\text { and in the other PRP + SC of } \\
\text { the bone marrow. }\end{array}$ & $\begin{array}{l}\text { DPSC greater osteogenic poten- } \\
\text { tial compared to bone marrow } \\
\text { cells. Both were able to integrate } \\
\text { the implant. The periosteal cells } \\
\text { that were also evaluated did not } \\
\text { manage to regenerate much bone } \\
\text { or osseointegrate. }\end{array}$ \\
\hline $\begin{array}{l}\text { Yamada et al. } \\
\text { (2010) }\end{array}$ & DPSCs & PRP & $\begin{array}{c}\text { Alveolar } \\
\text { bone y }\end{array}$ & Adult dogs & $\begin{array}{l}\text {-Extraction of the first molar } \\
\text { and premolars to dogs and } \\
\text { DPSCs. } \\
\text {-Adjustment of the bony } \\
\text { defect in the jaw. } \\
\text { - Sample of the bone ma- } \\
\text { rrow of the iliac crest of } \\
\text { each dog. } \\
\text { - Fill the defects randomly } \\
\text { with PRP, PRP + DPSCs } \\
\text { and PRP + SC of the bone } \\
\text { marrow. }\end{array}$ & $\begin{array}{l}\text { Good bone regeneration with } \\
\text { both DPSCs and bone marrow. } \\
\text { There was no rejection with } \\
\text { SHEDs of puppies. The regene- } \\
\text { rated bone in all cases was suita- } \\
\text { ble for implants. }\end{array}$ \\
\hline $\begin{array}{l}\text { Iohara et al. } \\
\text { (2009) }\end{array}$ & DPSCs & $\begin{array}{c}\text { Collagen } \\
\text { type I and III }\end{array}$ & Dental pulp & $\begin{array}{l}18 \text { adult dogs, } \\
54 \text { total teeth } \\
\text { were used. }\end{array}$ & $\begin{array}{l}\text { - DPSCs cameral extraction } \\
\text { of three dogs per dog. } \\
\text { - Filling of pulp chamber by } \\
\text { groups: } \\
\text {-Group 1: } 6 \text { teeth with } \\
\text { CD31- / CD146- cells } \\
\text {-Group 2: } 6 \text { teeth with CD31 } \\
\text { + / CD146- cells } \\
\text {-Group 3: } 6 \text { teeth with only } \\
\text { the collagen scaffold. }\end{array}$ & $\begin{array}{l}\text { Complete pulp regeneration } \\
\text { with vascularization and nerve } \\
\text { regeneration in the teeth with the } \\
\text { pulp amputated using the pulp } \\
\text { cells with CD31- and CD146-. } \\
\text { With CD31 + / CD146- cells. } \\
\text { Disordered regeneration, in } \\
\text { smaller quantity and lower } \\
\text { quality. Without cells there was } \\
\text { no regeneration. }\end{array}$ \\
\hline $\begin{array}{l}\text { Iohara et al. } \\
\text { (2004) }\end{array}$ & DPSCs & $\begin{array}{l}\text { Pellets + } \\
\text { BMP2 }\end{array}$ & Dentine & $\begin{array}{l}6 \text { young dogs, } \\
24 \text { teeth were } \\
\text { used in total. }\end{array}$ & $\begin{array}{l}\text { - DPSCs de los incisivos } \\
\text { superiores } \\
\text { - Trasplante con pellets las } \\
\text { DPSCs intracanal. }\end{array}$ & $\begin{array}{l}\text { Dentine formation when using } \\
\text { the pellet with BMP2 in the } \\
\text { middle and pulp mesenchymal } \\
\text { cells. }\end{array}$ \\
\hline
\end{tabular}

$13(61.9 \%)$ corresponded in vivo studies and $8(38,1 \%)$ corresponded humans studies. In relation to the mesenchymal stem cells, the mesenchymal stem cell of the dental pulp was the most used in a total of 14 articles $(60.8 \%)$, followed by the cells of the apical papilla used in 2 articles (9.5\%) (Fig. 2). In relation to the scaffolds the most used was atelocollagen, used in 5 (23.8\%) articles followed by PRP (platelet rich plasma) used in $3(14.2 \%)$ articles. $38 \%$ of the included articles had as main objective the use of mesenchymal cells is pulp regeneration, followed by alveolar bone regeneration with 37\% (Fig. 3).

\section{Discussion}

Clinical application and regeneration of oral tissues -Regeneration of the dentin-pulp complex $38 \%$ of the included studies studied pulp regeneration, and $21 \%$ dentin. Of the studies that evaluated the pulpal regeneration, in $44.4 \%$ they also evaluated the dentinal regeneration; therefore, it is seen that there is a relation between pulp and dentine regeneration.

Of the in vivo studies, all used MSCs from the dental pulp. Iohara et al. in 2009 (6) conducted a clinical trial where they used mesenchymal stem cells of the dental pulp (DPSCs) of dogs which were isolated by flow cy- 


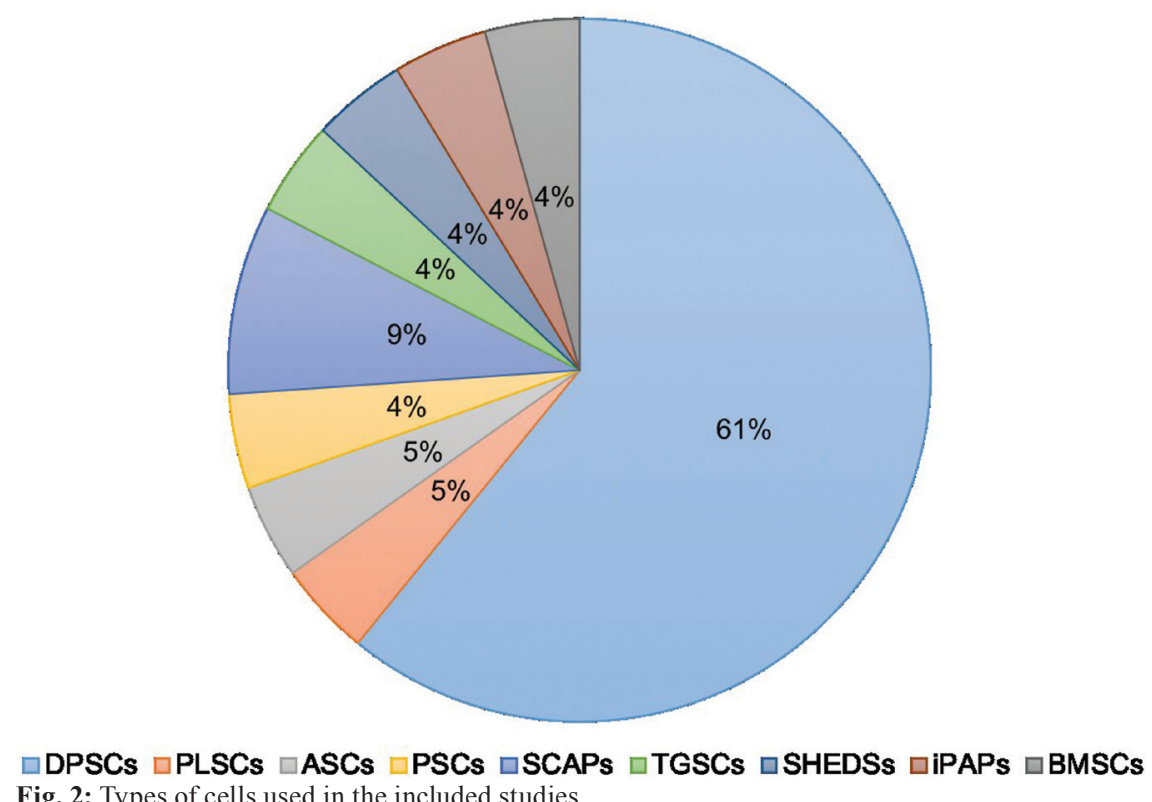

Fig. 2: Types of cells used in the included studies

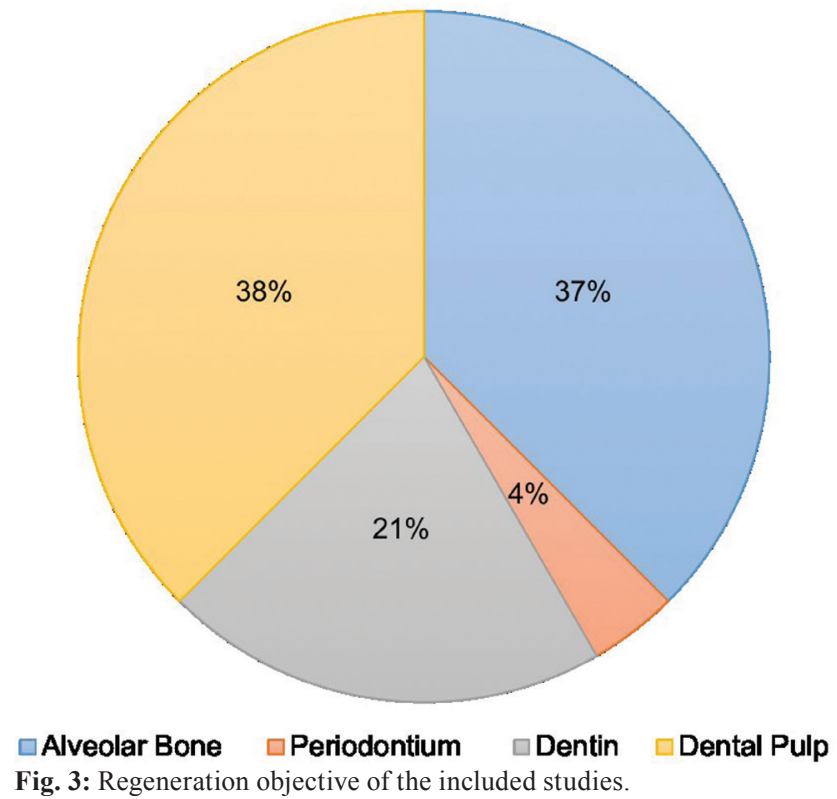

tometry which allowed them to obtain cells with surface markers CD31 - / CD31+ and CD146- which would correspond to a sub fraction of these DPSCs. The results obtained by a histological analysis showed the neoformation of vascular and neural tissue, as well as dental pulp inside the teeth that obtained cell transplantation CD31- / C146- and CD31+ / CD146-. But better and greater regeneration was obtained when using cells with the surface markers CD31- / C146-.

Other studies have seen the potential of CD105+ surface markers found in DPSCS. Iohara et al. in 2011 (7) con- ducted a study where they managed to isolate this cellular sub fraction by using Stromal Cell Derived Factor 1 (SDF-1). Complete pulp regeneration in dog's teeth was also observed by histological analysis.

According to the previously studies, pulp regeneration seems to be more effective when using mesenchymal stem cells with CD31- or CD105+ compared to those where they only use pulp mesenchymal stem cells without determining the sub fraction $(8,9)$.

Other cell isolation techniques have been further investigated since the safety of cells with CD31- and CD105+ 
surface markers isolated by flow cytometry has not been established and the use of SDF-1 has not been approved for clinical use (9). This is why Murakami et al. in 2015 (9) used granulocyte colony stimulating factor (G-CSF) to induce mobilization with the aim of isolating the sub fractions of the mesenchymal pulp stem cells. The results obtained cells with a cell phenotype similar to cells that have CD105 + with high angiogenic and neurogenic potential(9). Iohara et al. in 2013 (10) managed to regenerate whole pulp with the combination of G-CSF and DPSCs. When compared with the control, it was observed that the combination of both achieved the highest regenerative potential $(9,10)$.

Similar results were observed by Murakami et al. (9) who also used G-CSF and DPSCs achieving complete pulp regeneration with high rate of angiogenesis and neurogenesis. In 2016, Iohara et al. (11) conducted a new clinical trial in dogs where they used the same technique used in 2013 by this same author (10) who this time treated teeth with pulpal diagnosis of irreversible pulpitis. Unlike the studies mentioned above $(6,7,9,10)$ the evaluation of the animals was by magnetic resonance. The results of this study were also compared with histological methods and sensitivity test. The images made it possible to show that after 180 days there was regeneration of a more radiolucent dentinal tissue, which suggests that there is less mineralization of the dentin formed with the transplant of DPSCs (11). Mangione et al. (12)In 2017 they performed a Split Mouth randomized study in minipigs where, when comparing intervened and non-intervened teeth, pulp regeneration was not found when grafting DPSCs, an osteodentine with different characteristics was formed to a normal dentine. In the study by Iohara et al. in 2011 (7) they observed dentinal regeneration after transplantation of DPSCs. Therefore, they conclude that the DPSCs could allow the regeneration of the entire dentin-pulp complex.

Kodonas et al. in 2012 (13) performed a clinical trial in mini pigs with DPSCs. The histological results showed dentinal tissue formation in the canal walls, and the presence of Dentin Matrix Protein-1 was evidenced (DMP1) and Bone sialoprotein II (BSP-II) which indicate odontoblastic activity which would be responsible for this dentin formation.

Iohara et al. in 2004 (14) conducted a clinical trial with dogs and DPSCS. A greater degree of dentin formation could be observed when using pellets of mesenchymal stem cells treated with BMP-2. Gronthos et al. in 2000 (15) as in 2002 (16) had already tested dentinal regeneration when using humans but in immunocompromised mice and performing transplantation of xenogenic type. It was in the investigation of Iohara et al. in 2004 (14) that dentin was regenerated with autologous transplantation and in healthy animals without the requirement of immunocompromise or immunosuppression. By joining the MSCs with a pellet with BMP-2 in vitro, the extracellular matrix of the pellet can be used as a scaffold to manipulate the growth of cells in odontoblasts prior to transplantation. By establishing and optimizing this technique, a treatment with relevance for endodontic and cavities treatment could be achieved (14).

Studies in humans have also been conducted to achieve regeneration of the dentin tissue. In 2011, Lovelace et al. (17) conducted a clinical trial in which they performed a revascularization treatment in 8 patients with immature teeth and apical periodontitis. Both imaging and histology showed the apical closure of these immature teeth. This apical closure is explained by the presence of mesenchymal stem cells that reach the interior of the canal through apical bleeding. It is thought that said cells are SCAPs carried by the blood. However, a histological study conducted in 2010 by Wang et al. (18) showed that after a revascularization treatment in immature teeth diagnosed with pulpal necrosis or apical periodontitis, an apical closure was achieved but the root canals of the tooth were filled with ectopic bone tissue, fibrous tissue and cement apposition $(11,18)$. More recent studies such as that of Nakashima et al. in 2017 (19) carried out a pilot study where they transplanted DPSCs obtained from teeth with irreversible pulpitis. Clinically, histologically and imaging, regeneration of the pulp and dentin could be seen with a sensitivity and vitality of the pulp almost normal in pulpectomized teeth.

-Regeneration of the alveolar bone

$48 \%$ of the articles included in this review studied bone regeneration. Multiple authors have used DPSCs to regenerate alveolar bone. Ito et al. in 2011 (20) conducted an in vivo clinical trial in which they used DPSCs. The analysis of the results in radiographic, histological and clinical form showed good bone regeneration using the MSCs, observing a greater amount of bone compared to the control. Regarding the dental implant (IOI), although in both cases they were osseointegrated, it was observed that in the area where the mensenchymal stem cells were used there was more bone around the implant compared to the control.

Yamada et al. in 2011 (21) conducted a clinical trial in animals, in which they also obtained bone regeneration after the transplant of DPSCs in the bone defect after a tooth extraction. Yamada et al. in 2010 (22) performed a study similar to the previous one in which they tested the capacity of this regenerated bone for the osseointegration of implants. The results obtained showed correct osseointegration when using the different types of mesenchymal stem cells.

Monti et al. in 2016 (23) conducted a clinical trial in humans with 6 patients. The alveoli after the extraction were filled with a collagen sponge and DPSCs, other defects were only filled with the collagen sponge as a control. After imaging and clinical analysis, it was observed 
that the regenerated alveolar bone where DPSCs were implanted was more mature and of higher quality than in the control group after 60 days had elapsed. In addition, the bone regenerated with cells was apt to be rehabilitated based on IOI. However, in the study by Barbier et al. in 2018 (24) filled out post-extraction alveoli with DPSCs and a collagen scaffold and did not find a greater bone regeneration of the defect due to impacted third molar extraction when using DPSCs.

Mesenchymal stem cells of the periosteum have been able to regenerate alveolar bone. Mouraret et al. in 2014 (25) conducted a clinical trial in animals where they created a vertical defect in mice at the palatal level which was filled with a collagen sponge with periosteum. It was compared to a tunneling technique without the use of a scaffold that was a collagen sponge. When the collagen sponge was not used, bone resorption was observed. Therefore, it was demonstrated that the periosteum has mesenchymal stem cells that participate in bone regeneration, but with the help of a scaffold such as collagen, for example.

Shiehzadeh et al. 2014 (26) reported three cases in which they sought to repair bone defects of periapical lesions in teeth with apical peridontitis. For this, in three different patients, they carried out protocols with different mesenchymal stem cells. The first case used SCAPs, the second case used SHEDs and the third case used cells obtained with a new method in this study that obtained cells from the periapical tissues through the canal (iPAPs). With a radiographic method it was possible to see the repair of the lesions together with the apical closure of the immature teeth, clinically there were no complications or symptomatology after the treatment.

Chen et al. in 2016 (27) conducted a randomized clinical trial in humans, where they used mesenchymal stem cells of the periodontal ligament (PLSCs). In 30 patients, 41 teeth were intervened in total with periodontal defects, which were treated with PLSCs obtained from previously extracted third molars. Although radiological and clinically greater regeneration was seen when using MSC, the difference was not statistically significant after 12 months. Khojasteh et al. in 2016 (28) conducted a human clinical trial this time using cells from the adipose body of the cheek (ASCs). The clinical, histological and radiographic evaluation of the patients showed that combining the scaffold with the mesenchymal stem cells obtained better bone regeneration with good volume and preventing postoperative bone resorption (28).

Redondo et al. in 2018 (29) conducted a pilot study where they obtained BMSCs of maxillary bone and managed to regenerate the alveolar bone in cavities of maxillary radicular cysts when using scaffolding of Serum cross liked scaffold.

-Regeneration of the periodontium

One study $(5,8 \%)$ described the regeneration of perio- dontal tissues in animals. In the clinical trial of Nakajima et al. (30) conducted in 2014, mesenchymal stem cells were extracted from the granulation tissue (TGSCs) generated in alveoli after performing premolar extraction. The regeneration obtained was analyzed histologically, which resulted in a periodontium with periodontal ligament, cement and bone. The origin of these cells still uncertain, being likely to come from remains of the periodontal ligament, the apical papilla, the alveolar bone or surrounding MSCs. This is why the granulation tissue cannot yet be determined as a proper niche of stem cells. Studies have been found with allogenic mesenchymal stem cells that have demonstrated the ability of mesenchymal stem cells to regenerate the periodontium.

-Comparison with extraoral mesenchymal stem cells

In 2015, Murakami et al. (9) compared the pulp mesenchymal stem cells with those of the bone marrow of the sternum. The protocol carried out was the same, only that the origin of the mesenchymal cell used changed. The results showed that in order to regenerate the dental pulp, the bone marrow cells obtained a greater quantity of pulp matrix, but the cells of the dental pulp managed to regenerate greater vascularization and innervation. Yamada et al. in 2004 (31) studied the use of mesenchymal stem cells of the bone marrow in order to regenerate alveolar bone for implants, thus regenerating a functional bone for it. Then Yamada et al. in their 2011 studies (21) and 2010 (22) also compared DPSCs and SHEDs with the BMSCs of the iliac crest but this time in order to regenerate bone alveolar. The results showed a good bone regeneration by the three types of cells, and bone apt to rehabilitate with implants. Therefore, DPSCs and SHEDs could be an alternative to regenerate bone, obtaining the same results as with BMSCs. In the study by Ito et al. in 2011 (20) they also compared the DPSCs with the BMSCs to regenerate the alveolar bone, they observed greater osteogenic potential from the DPSCs, although both cell types regenerated bone suitable for osseointegrating implants.

Finally, there are intraoral studies with extra oral mesenchymal stem cells specifically of adipose tissue of the abdomen. In the study by Murakami et al. 2015 (9) they compared the DPSCs with the ASCs of the abdomen. The results were the same as with the BMSCs, that is, obtaining pulp matrix but with less vascularization and innervation compared to that obtained with DPSCs. Iohara et al. in their 2011 study (7) compared DPSCs with ASCs in order to regenerate dental pulp and dentin for apical closure. The histological results showed a low potential of the fat cells to regenerate the dentin-pulp complex.

In conclusion, although most of the studies were performed in vivo, it can be noted that PLSCs, DPSCs, ASCs, SCAPs, SHEDs were able to regenerate alveolar bone, DPSCs and SCAPs the dentin-pulp complex and the 
TGSCs the periodontium. It should be noted that the studies used in this review are not of high quality, so there is a need in the literature to conduct more randomized controlled clinical trials with a larger sample size and homogeneity in follow-up times so that the results obtained are truly significant. and extrapolated to clinical use. It is necessary to mention that not only the cells influence the results, so the use of different scaffolds and biomolecules in the environments in the different studies means that these are not really comparable. This is why it is necessary to standardize the studies with the same scaffolds and biomolecules in order to effectively compare the results obtained using mesenchymal stem cells from different areas in the same environment. Although to date it can be concluded that the results obtained when regenerating using mesenchymal stem cells are positive, it is necessary to determine the best scaffolding and the best means to obtain the best results.

\section{References}

1. Sanz AR, Carrión FS, Chaparro AP. Mesenchymal stem cells from the oral cavity and their potential value in tissue engineering. Periodontol 2000. 2015;67:251-67.

2. Flores-Figueroa E, Montesinos JJ, Mayani H. Células troncales mesenquimales: Historia, biología y aplicación clínica. Rev Investig Clin. 2006;58:498-511.

3. Risbud MV, Shapiro IM. Stem cells in craniofacial and dental tissue engineering. Orthod Craniofacial Res. 2005;8:54-9.

4. Chen Y, Shao JZ, Xiang LX, Dong XJ, Zhang GR. Mesenchymal stem cells: A promising candidate in regenerative medicine. Int J Biochem Cell Biol. 2008;40:815-20.

5. Liu J, Yu F, Sun Y, Jiang B, Zhang W, Yang J, et al. Concise reviews: Characteristics and potential applications of human dental tissue-derived mesenchymal stem cells. Stem Cells. 2015;33:627-38.

6. Iohara K, Zheng L, Ito M, Ishizaka R, Nakamura H, Into T, et al. Regeneration of dental pulp after pulpotomy by transplantation of CD31(-)/CD146(-) side population cells from a canine tooth. Regen Med. 2009;4:377-85.

7. Iohara K, Imabayashi K, Ishizaka R, Watanabe A, Nabekura J, Ito $\mathrm{M}$, et al. Complete Pulp Regeneration After Pulpectomy by Transplantation of CD105 + Stem Cells with Stromal Cell-Derived Factor-1. Tissue Eng Part A. 2011;17:1911-20.

8. Nakashima M, Iohara K. Regeneration of Dental Pulp by Stem Cells. Adv Dent Res. 2011;23:313-9.

9. Murakami M, Hayashi Y, Iohara K, Osako Y. Trophic Effects and Regenerative Potential of Mobilized Mesenchymal Stem Cells from Bone Marrow and Adipose Tissue as Alternative Cell Sources for Pulp / dentin Regeneration. Cell Transplant. 2015;24:1753-65.

10. Iohara K, Murakami M, Takeuchi N, Osako Y, Ito M, Ishizaka R, et al. A Novel Combinatorial Therapy With Pulp Stem Cells and Granulocyte Colony-Stimulating Factor for Total Pulp Regeneration. Stem Cells Transl Med. 2013;2:521-33.

11. Iohara K, Fujita M, Ariji Y, Yoshikawa M, Watanabe H, Takashima A, et al. Assessment of pulp regeneration induced by stem cell therapy by magnetic resonance imaging. J Endod. 2016;42:397-401.

12. Mangione F, Ezeldeen M, Bardet C, Lesieur J, Bonneau M, Decup F, et al. Implanted Dental Pulp Cells Fail to Induce Regeneration in Partial Pulpotomies. 2017;96:1-8.

13. Kodonas K, Gogos C, Papadimitriou S, Kouzi-Koliakou K, Tziafas D. Experimental formation of dentin-like structure in the root canal implant model using cryopreserved swine dental pulp progenitor cells. J Endod. 2012;38:913-9.

14. Iohara K, Nakashima M, Ito M, Ishikawa M, Nakasima A, Akamine
A. Dentin regeneration by dental pulp stem cell therapy with recombinant human bone morphogenetic protein 2. J Dent Res. 2004;83:590-5. 15. Gronthos S, Mankani M, Brahim J, Robey PG, Shi S. Postnatal human dental pulp stem cells (DPSCs) in vitro and in vivo. Proc Natl Acad Sci USA. 2000;97:13625-30.

16. Gronthos S, Brahim J, Li W, Fisher LW, Cherman N, Boyde A, et al. Stem Cell Properties of Human Dental Pulp Steam Cells. J Dent Res. 2002;81:531-5.

17. Lovelace TW, Henry MA, Hargreaves KM, Diogenes A. Evaluation of the delivery of mesenchymal stem cells into the root canal space of necrotic immature teeth after clinical regenerative endodontic procedure. J Endod. 2011;37:133-8.

18. Wang X, Thibodeau B, Trope M, Lin LM, Huang GTJ. Histologic Characterization of Regenerated Tissues in Canal Space after the Revitalization/Revascularization Procedure of Immature Dog Teeth with Apical Periodontitis. J Endod. 2010;36:56-63.

19. Nakashima M, Iohara K, Murakami M, Nakamura H, Sato Y, Ariji $\mathrm{Y}$, et al. Pulp regeneration by transplantation of dental pulp stem cells in pulpitis : a pilot clinical study. Stem Cell res Ther. 2017;8:1-13.

20. Ito K, Yamada Y, Nakamura S, Ueda M. Osteogenic potential of Effective bone engineering using dental pulp stem cells, bone marrow stem cells and periosteal cell for osseointegration of dental implants. Int J oral Maxillofac Implant. 2011;26:947-54.

21. Yamada Y, Ito K, Nakamura S, Ueda M, Nagasaka T. Promising ce11-based therapy for bone regeneration using stem cells from deciduous teeth, dental pulp, and bone marrow. Cell Transplant. 2011;20:100313.

22. Yamada Y, Nakamura S, Ito K, Sugito T, Yoshimi R, Nagasaka T, et al. M. A Feasibility of Useful Cell-Based Therapy by Bone Regeneration with Deciduous Tooth Stem Cells, Dental Pulp Stem Cells, or Bone-Marrow-Derived mesenchymal stem cells for clinical study using tissue engineering technology. Tissue Eng Part A. 2010;16:1891-900 23. Monti M, Graziano A, Rizzo S, Perotti C, Del Fante C, D'Aquino R, et al. In Vitro and In Vivo Differentiation of Progenitor Stem Cells Obtained After Mechanical Digestion of Human Dental Pulp. J Cell Physiol. 2016;232:548-55.

24. Barbier L, Ramos E, Mendiola J, Rodriguez O, Santamaria G, Santamaria J, et al. Autologous dental pulp mesenchymal stem cells for inferior third molar post-extraction socket healing: A split-mouth randomised clinical trial. Med Oral Patol Oral Cir Bucal. 2018;23:e469-e477. 25. Mouraret S, Von Kaeppler E, Bardet C, Hunter DJ, Chaussain $\mathrm{C}$, Bouchard $\mathrm{P}$, et al. The potential for vertical bone regeneration via maxillary periosteal elevation. J Clin Periodontol. 2014;41:1170-7.

26. Shiehzadeh V, Aghmasheh F, Shiehzadeh F, Joulae M, Kosarieh E, Shiehzadeh F. Healing of large periapical lesions following delivery of dental stem cells with an injectable scaffold: new method and three case reports. Indian J Dent Res. 2014;25:248-53.

27. Chen FM, Gao LN, Tian BM, Zhang XY, Zhang YJ, Dong GY, et al. Treatment of periodontal intrabony defects using autologous periodontal ligament stem cells: a randomized clinical trial. Stem Cell Res Ther. 2016;7:33.

28. Khojasteh A, Sadeghi N. Application of buccal fat pad-derived stem cells in combination with autogenous iliac bone graft in the treatment of maxillomandibular atrophy: A preliminary human study. Int J Oral Maxillofac Surg. 2016;45:864-71.

29. Redondo LM, García V, Peral B, Verrier A, Becerra J, Sanchez A, et al. Repair of maxillary cystic bone defects with mesenchymal stem cells seeded on a cross-linked serum scaffold. J Craniomaxillofac Surg. 2018;46:222-9.

30. Nakajima R, Ono M, Hara ES, Oida Y, Shinkawa S, Pham HT, et al. Mesenchymal Stem/Progenitor Cell Isolation from Tooth Extraction Sockets. J Dent Res. 2014;93:1133-40.

31. Yamada Y, Ueda M, Naiki T, Nagasaka T. Tissue-engineered injectable bone regeneration for osseointegrated dental implants. Clin Oral Implants Res. 2004;15:589-97.

\section{Conflict of interest}

No conflicting interests. 